\title{
Public Perceptions of the Legal Handling of Sexual Violence in Youth Sport in Canada: An Unobtrusive Analysis of the Graham James Case
}

\author{
Curtis Fogel ${ }^{1} \&$ Chadd Sine ${ }^{1}$ \\ ${ }^{1}$ Interdisciplinary Studies- Criminology, Lakehead University, Orillia, Canada \\ Correspondence: Curtis Fogel, Interdisciplinary Studies, Lakehead University, Orillia L3V 0B9, ON., Canada. \\ Tel: 1-705-330-4008 ext. 2646. E-mail: cafogel@lakeheadu.ca
}

Received: February 21, 2013 Accepted: March 7, 2013 Online Published: July 5, 2013

doi:10.5539/ilr.v2n1p116 URL: http://dx.doi.org/10.5539/ilr.v2n1p116

\begin{abstract}
In 2012, one of the most widely publicized Canadian cases of sexual violence in Canadian youth sport resurfaced on the national newsstands. Graham James, a former Hockey News Man of the Year, was arrested on allegations that he engaged in long-term non-consensual sexual relations with youth Canadian hockey players he was coaching. This arrest came on the heels of a previous jail sentence in 1997 for sexually assaulting three hockey players he had coached, which he later received a pardon for. In March of 2012, James was sentenced to two years in prison, which was subsequently increased to five years on appeal in 2013. This paper examines public perceptions of the legal handling of this case through the unobtrusive analysis of 1024 comments posted electronically following an online media article pertaining to the initial two-year sentence in 2012. Through the unobtrusive data analysis, several themes emerged including: a) arguments for a harsher punishment, b) perceived failings of the Canadian Criminal Justice System, c) criticism of Canadian political parties and current government, d) indifference to the sentence, e) appreciation of the courage of the victims in coming forward with their complaints, and f) perceived failings of sports organizations in preventing sexual abuse.
\end{abstract}

Keywords: sexual violence, hockey, Canadian Criminal Justice System

\section{Introduction}

On March 20, 2012 former Canadian junior hockey coach Graham James was sentenced to two years in prison for sexually assaulting two former players - former National Hockey League (NHL) player Theoren Fleury and Fleury's younger cousin, Todd Holt- while coaching them two decades previously. This arrest and conviction came on the heels of a previous prison sentence James received in 1997 for sexually assaulting three other young Canadian hockey players he had coached including Sheldon Kennedy, another former NHL hockey player. While a brief national spotlight was placed on Graham James and his athlete-celebrity victims, very little media and academic attention has been given to the larger issue of sexual violence in amateur Canadian sport. Using this high-profile case, this paper seeks to provide a preliminary enquiry into the public perceptions and responses to how the Canadian Criminal Justice System responds to sexual violence in Canadian youth sport. Public perceptions of this incident are explored through an unobtrusive analysis of 1024 comments posted electronically following an online media article pertaining to the violent acts and initial two-year sentence (CBC News, 2012).

This paper begins with a review of the literature on the existing empirical research pertaining to sexual violence, abuse, and harassment in sport. The unobtrusive methodological approach used in this study will then be highlighted. Through the unobtrusive data analysis, several themes emerged surrounding public perceptions of the legal handling of sexual violence in sport that will be discussed in detail. These themes include: a) arguments for a harsher punishment, b) perceived failings of the Canadian Criminal Justice System, c) criticism of Canadian political parties and current government, d) indifference to the sentence, e) appreciation of the courage of the victims in coming forward with their complaints, and f) perceived failings of sports organizations in preventing sexual abuse. 


\section{Literature Review}

Few academic literatures are as vast as the topic of sexual violence. Common areas of inquiry on sexual violence include: sexual assault prevention ${ }^{1}$, experiences of sexual violence, harassment, and abuse ${ }^{2}$, reporting rates of sexual assault ${ }^{3}$, relationships between drug use, sexual offending, and sexual victimization ${ }^{4}$, mental health aspects of recovering from or surviving sexual assault ${ }^{5}$, investigation of sex crimes $^{6}$, treatment approaches for survivors of sexual violence ${ }^{7}$, male roles in the perpetration of sexual violence ${ }^{8}$, Feminist Theory applications to sexual violence ${ }^{9}$, policing of sex crimes ${ }^{10}$, legal processes related to sex crime trials ${ }^{11}$, and legal reform of Canadian sexual assault laws ${ }^{12}$.

While important and compelling, the existing literature on sexual violence in sport has yet to develop and keep up with the larger body of sexual assault literature it is situated within. Some of the topics that have been researched include: the disproportionate perpetration of sexual violence by male athletes ${ }^{13}$, prevention and protection strategies for women and children in sport ${ }^{14}$, noting the absence of empirical research and theoretical analyses on sexually abused male children in sport ${ }^{15}$, examining intimate relationships between athletes and coaches $^{16}$, theoretical explanations for sexual harassment and abuse in sport ${ }^{17}$, studies on the occurrence of sexual harassment in specific sporting contexts and organizations ${ }^{18}$, institutional and community responses, or lack thereof, to sexual violence in sport ${ }^{19}$, examinations of sexual violence in the context of hazing in sport ${ }^{20}$, and emotional experiences of the researcher in study sexual abuse in sport ${ }^{21}$.

One limitation of the existing literature on sexual assault in sport is that the vast majority of research has been conducted in Europe, with some important Canadian research completed but not a significant quantity of research by comparison. Another limitation is that much of the research has relied upon psychological theories and explanations drawing on individual case studies with minimal attention to social structures and cultural contexts of sport and the society it is situated within, with minimal consideration given to the role of the

\footnotetext{
${ }^{1}$ Anderson \& Whiston, 2005; Casel \& Lindhorst, 2009; Fisher, Daigle, \& Cullen, 2008; Jones \& Cook, 2008; Koss et. al, 2003; Lonsway, 1996.

2 Anderson et. al, 2004; Arata, 1999; Bohner, 2009; Campbell 2008; Campbell et. al, 2001; Jordan, 2008; Lievore, 2005; Peterson \& Muelenhard, 2004; Williams \& Holmes, 1981.

${ }^{3}$ Bachman, 1993; Rumney, 2006.

${ }^{4}$ Abbey et. al, 2004; Finch \& Munro, 2005, 2007; Groeneveld \& Shane, 1989; Horvath \& Brown, 2007; McFarlane, et. al, 2005; McGregor et. al, 2004; Ullman, 2003.

${ }^{5}$ Bagley et. al, 1997; Campbell, 1998, 2008; Campbell, \& Raja, 1999; Campbell, Dworkin, \& Cabral 2009; Firsten, 1990; Ullman \& Fillipas, 2001.

${ }^{6}$ Harris \& Grace, 1999; Quinlan, Fogel, \& Quinlan, 2011.

${ }^{7}$ Beres, Crow, \& Grotell, 2009; Campbell, \& Ahrens, 1998; Campbell \& Bybee, 1997; Campbell, et. al, 2005.

${ }^{8}$ Berkowitz, 2002; DeKeseredy \& Kelly, 1995; Kirkpatrick \& Kanin, 1957; Murnen, Wright, \& Kaluzny, 2002; Sanday, 1990; Schwartz, \& DeKeseredy, 1997; Weiss, 2009.

${ }^{9}$ Brownmiller 1975; Clark, \& Lewis, 1977; Dobash et. al, 1992; Frith, 2009; Maier, 2008; Quinlan, 2012; Russell, 1975; Sanday, 1981; Ward, 1995

${ }^{10}$ DuMont, Miller, Myhr, 2003; Griffiths, 1999; Jordan, 2004.

${ }^{11}$ Busby, 2007; DuMont \& Myhr, 2000; Gotell, 2007, 2002; McIntyre et. al, 2000; Randall, 2008; Sanday, 1996; Temkin, 2002; Tempkin \& Krahe, 2008.

${ }^{12}$ Chase, 1984; Clark, \& Hepwoth, 1994; Cohen \& Backhouse, 1980; Denike, 1994; Roberts \& Gebotys, 1992; Roberts, Grossman, \& Gebotys, 1996; Sheehy, 1996.

${ }_{13}$ Benedict 1997; Benedict \& Klein 1997; Benedict \& Yaeger 1998; Caron et al. 1997; Crosset et al. 1995; Leahy et al. 2002; Pappas et al. 2004; Robinson 1998; Smith \& Stewart 2003.

${ }^{14}$ Boocock 2002; Brackenridge 1998, 2001, 2003, 2004; Fasting et al. 2008; Hartill \& Prescott 2007; Kirby et al. 2008; Leahy 2008; Lyons 2002; Parrot \& Cummings 2004; Welch 1997.

${ }^{15}$ Hartill 2005, 2008.

${ }^{16}$ Fasting and Brackenridge 2009; Nielsen 2001

${ }^{17}$ Brackenridge 1994, 1997, 2001; Kane \& Disch 1993.

${ }^{18}$ Brackenridge \& Fasting 2002; Cense \& Brackenridge 2001; Donnelly 1999; Fasting et al. 2002, 2004, 2007; Kirby 1995; Kirby et al. 2000; Marks et al. 2011; Volkwein-caplan \& Sankaran 2001; Volkwein-caplan et al. 1997, 2002; Yves et al. 2008.

19 Jackson 1991; Lefkowitz 1997; Markovitz 2006; Parent 2011.

${ }^{20}$ Kirby \& Wintrup 2002; Robinson 1998.

${ }^{21}$ Brackenridge 2003.
} 
Criminal Justice System in responding to these crimes. A third limitation, as described in detail by Hartill (2005, 2008), is that research on male victimization related to sexual violence in sport is almost non-existent. Fourth, minimal attention has been given to examining the perceptions the Canadian public have on the ways in which the Criminal Justice System handles sexual violence in sport. This study contributes to each of these limited areas of research on sexual violence in sport, and research on sexual assault more generally.

\section{Methodology}

Following Webb et. al (2000), this research uses an unobtrusive method of data collection, which is sometimes referred to as a non-reactive method. This method requires no human contact for the purposes of developing research data and instead relies on existing information as data. Furthermore, the existing information that is used as data has typically not been created with the intent that it will be used for academic research. The responses provided by readers of a media article are unobtrusive in that the respondents did not write their responses with the belief or purpose that their responses would be used for research purposes.

The data used for this paper consists of 1024 comments posted electronically following a media article pertaining to a report on Graham James's 2012 sentencing. The data collected was coded using what Glaser and Strauss (1967) term "open coding", which involved the purposive thematic coding of all comments pertaining to perceptions of the legal handling of sexual violence in youth sport in Canada. In some instances, different sections of specific comments were coded into different themes. This unobtrusive approach allowed for the accessible examination of public perceptions of the legal handling of sexual violence in Canadian sport through the case of R. v. James (2012). The reactive potential within face-to-face interviews, surveys and experimental designs was thus avoided through this approach. Furthermore, this approach allowed for a large sample of participants with 1024 comments being posted.

A limitation of this methodology is that the study's accuracy in depicting public perceptions of the legal handling of sexual assault in youth sport is limited to the data that were used. The use of unobtrusive data prohibited the possibility of questioning the individuals who posted comments further about their perceptions. Furthermore, no demographic information was available on who the individuals were who posted comments, such as whether they were male or female, sports fans or not, Canadian or non-Canadian, their age, or other potentially relevant variables to consider. Furthermore, this study only examines a single case study involving one perpetrator and several athletes. It is thus limited in scope in that it does not examine the countless other cases of sexual violence in Canadian sport that generate less publicity and public response. Given these limitations, this paper is not intended to provide a final say on the topic of public perceptions of the legal handling of sexual violence in Canadian youth sport but rather, the aim is to provide a preliminary examination of the topic using a novel methodological approach that could be followed up with further qualitative and quantitative approaches to social enquiry.

\section{Background}

The sentencing hearing of R. v. James (2012), took place on March $20^{\text {th }}, 2012$ in the Provincial Court of Manitoba. James was living and working in Mexico when he was charged with sexually assaulting Theoren Fleury and Todd Holt across the time span of 1983 to 1994. James willingly returned to Canada and was held to face the charges. On December $7^{\text {th }}, 2011$ James entered guilty pleas for both of the sexual assault charges laid against him. He was sentenced to two years in prison. In the time since this unobtrusive study was conducted that sentence has been increased to five years following an appeal by the prosecution.

Graham James was previously convicted January $2^{\text {nd }}, 1997$ for the sexual assault of Sheldon Kennedy and another unnamed player. James was sentenced to three and a half years in jail and then paroled in 2001 for those crimes. He then received a pardon for the offences on January 8, 2007. After this, he returned to coaching in the country of Spain, where he was the assistant coach of the national hockey team, before then moving on to live in Mexico. Since his first conviction in 1997, James has not been reported for the commission of any recent sexual offences or related crimes. During his first prison term, James completed a sex offender rehabilitation program and elected to remain in the program voluntarily delaying an early parole. During this program it has been reported that James came to the realization that the acts he committed were forced upon unwilling individuals.

Before his arrest in 1997 on the initial sexual assault charges, Graham James had an illustrious coaching career in Canadian junior hockey. His coaching career began in 1979 coaching the Fort Garry Blues (The Star, 2012). He then coached in the Western Hockey League (WHL) over the next decade and a half. During that time, he achieved great success as a coach, winning WHL titles in 1989 and 1993 with the Swift Current Broncos. In 1989 James was named The Hockey News "Man of the Year". During this run of coaching success he was privately sexually abusing players that he coached. 
Multiple victims involved in this case were under the age of 18 when the sexual assaults started. During the time of the offences, James was in a position of authority and trust over each of the victims involved. James used this authority to manipulate the victims to give them no choice but to conform or lose everything that they had worked towards. The assaults were repeated over many years to multiple victims, and at times were overlapping with another victim. Each case had similar patterns, which showed that James groomed each victim into a position in which they could not refuse his advances. As presented in the victim impact statements written by Theoren Fleury and Sheldon Kennedy, the damages were long term and devastating to the victims as well as the people around them.

All of the victims who have come forward were at one time promising hockey players. All three named victims were eventually drafted into the NHL and due to the public stardom of the victims this case received widespread media attention. The case against James could be the highest profile sexual assault case in Canadian history, spanning fifteen years. During this time James has been publically scrutinized through the various media sources over a prolonged period of time, while the victims of his crimes have also remained in the spotlight.

\section{Research Findings}

Not every comment that was posted was coded into a theme. Many of the comments were simply not of direct relevance to examining public perceptions of sexual violence in youth sport in Canada. For example, many posts identified spelling and grammar mistakes made by other commenters. Many other posts were links to other articles on the Graham James case. Others were factual statements on the basic workings of the Canadian Criminal Justice System. Some comments on religion were made that appeared out of context. Other comments made no discernable sense at all. The vast majority of comments did, however, provide insight into how the public perceives the legal handling of the sex crimes perpetrated by Graham James against young hockey players that he coached.

\subsection{Arguments for a Harsher Punishment}

The most common response by commenters was that the sentence Graham James received was too lenient. 292 commentators argued that two years in prison for repeated acts of sexual assault and exploitation of young hockey players is not a sufficient penalty. Of these comments on sentence length, the most frequent response was to propose a longer sentence that would be more just and fair. The current lenient sentence was perceived to "issue hunting licenses for sexual predators in Canada."

Many indicated that a life sentence would be the only fair response. According to one commenter, "I have every reason to believe that James should be locked away for the remainder of his natural life, because I've seen what happens to the victims. They serve life sentences, they may heal, but they serve life sentences." Similarly, another wrote, "2 years in prison for him....the rest of their lives in prison for his victims. The world is broken." Another wrote, "How this judge can give this monster a slap on his fingers for the atrocities he has committed against these young boys makes me physically sick to my stomach. Graham James should be locked away for the rest of his life for what he has done."

Others indicated that a life sentence would not be enough. In Canada, a life sentence is currently 25 years in prison without parole. Many commenters indicated that he should never be allowed to be eligible for parole and should spend the rest of his life in prison. One commenter wrote, "Two years is about 200 years short." Another wrote, "There are 2 numbers missing, it should read: 222 years."

Others proposed even more severe punishment than the length of time he should spend in prison. Several commenters indicated that they thought the death penalty should be brought back in Canada to punish child sexual offenders. One commenter wrote, "The penalty should have been death." Others suggested that the Canadian Criminal Justice System should revert back to the use of torture as a public spectacle and deterrent, such as, "James deserves to be whipped in public." Others made comments like "James deserves some good ol" fashioned prison justice" whereby he is regularly assaulted violently and sexually by other prison inmates while serving his time in prison.

\subsection{Perceived Failings of the Canadian Criminal Justice System}

The second most common theme overall, with 215 comments, was that the Canadian Criminal Justice System has failed in handling sexual violence in youth sport. Many commenters directed criticism directly at the justice system for failing to ensure that justice is being done. One commenter wrote, "It's not the justice system anymore, it's just the system." Another wrote, "Our justice system is not a justice system at all. It is a catch and release system." Another simply stated, "Our Justice System is failing us!" Many referred to the Canadian 
Criminal Justice System as "a joke" suggesting that Canada merely has "a pretend justice system." Another commenter came to the conclusion that in Canada "apparently justice truly is 'blind', deaf, dumb and stupid."

A major failing in the Canadian Criminal Justice System that many commenters perceived was a belief that offenders seemingly have more rights than victims of child sexual abuse. One commenter wrote, "In Canada victims are punished and criminals are protected!" Another wrote, "The justice system in this case grossly failed the victims and everyone in our country." Similarly, a commenter stated, "To his victims I say I am very sorry that you have been abused again, this time by 'the system' itself. You were abused, you were harmed and you deserved to be treated better by the Courts." Another wrote, "Another travesty committed by our justice system. The victim has no one to protect them. That is what the justice system is supposed to do. Sometimes you have to ask, who is worse, the offender or the justice system in some cases."

Another perceived failing of the Canadian Criminal Justice System that garnered many comments centered on the competency of the judge who presided over the trial and decided on the two year sentence. One commenter wrote, "this judge sentenced herself to a lifetime of shame." Another suggested that, "The people of Canada expect more from their judges who are supposed to represent fairness for crimes committed. Do us all a favour and get off the bench Judge Carlson." Another wrote, "What a travesty, the judge should get 2 years in prison."

\subsection{Criticism of Canadian Political Parties and Current Government}

The third most common response was to direct criticism to one of the three main political parties in Canada: Conservative Party, Liberal Party, or New Democratic Party. 124 comments were made that were in criticism of a Canadian political party. The most common of these responses was to suggest that the perceived lenient sentence and failings of the Canadian Criminal Justice System could be traced back to a single political party. Different commenters pointed their fingers at different political parties, with the Conservative Party taking the most criticism as the party currently in office in Canada.

Among the criticisms waged against Stephen Harper and his Conservative Party, the most common was to criticize Bill C-10, which centers on getting tough on crime and imposing mandatory minimum sentences for certain offences. Many commenters responded to perceived inconsistencies in the Conservative initiative to develop safer communities. The most common inconsistency pointed out by commenters was the new penalties now imposed on Canadians for marijuana-related offences; a drug perceived by many to be less harmful than alcohol, nicotine, and even caffeine. One commenter wrote, "In Stephen Harper's Canada, if you want to get a proper sentence for a convicted sex offender who destroys the lives of pubescent and late pubescent children and men, you have to indict him with a marijuana-related offence." Another wrote, "Perhaps if someone had planted some weed on this guy he would have done more time. The government has the priorities for public safety messed up." Similarly, another stated, "Stephen Harper and The Cons new campaign slogan: Tough on Pot Plants, Soft on Pedophiles."

\subsection{Indifference to the Sentence}

The fourth most common response in general was to express indifference to the two-year sentence that Graham James received. 43 respondents made comments that showed some indifference to the sentence. One common response was explanations for how the judge had acted within her constraints of law, precedent, and procedure. While these respondents might not have agreed with the sentence length, they expressed understanding for why they thought it should be in place.

Others thought the sentence length was not of central importance, as punishment was not perceived as an effective deterrent for sex offenders. Arguing this, one commenter wrote, "If the torch-and-pitchfork crowd can point to one instance in the history of humankind where harsh sentences have prevented crime, this would be the time and place to bring it forward." Another commented, "There is no sentence long enough or harsh enough to make people happy. It is widely known that longer, harsher sentences don't function as deterrents, especially in cases of sexual abuse, which is widely believed to be a mental illness. Even a death sentence from James won't stop the next abuser from preying on kids."

Many others also expressed a belief that the time in prison that Graham James serves will be much harsher than the experience of most inmates because of the heinous crimes he has committed. Detailing this, one commenter wrote, "Being that it's 2 years, it's going to be a long 2 years, because in PC [protective custody], even the other guys in PC hate 'kiddly diddlers'. He's going to have a lot of fun eating every meal and wondering what's in it every day." Another commented, "Just make sure he is integrated into the normal inmate population and not segregated. See how the predator becomes the prey." 


\subsection{Appreciation of the Courage of the Victims}

A fifth common theme that emerged from the comments was to express appreciation to the victim's for having the courage to come forward with their complaints of sexual abuse. 33 comments of this sort were made, many by individuals who identified as victims of child sexual abuse themselves when they were younger. One commenter wrote, "These men were very brave to come forward and expose Graham James. They have done what they could and hopefully having the issue out in the open will bring discussion and change for the future." Another wrote, "When will Sheldon Kennedy be given the Order of Canada? He stood up to this pig years ago, and at great personal risk, laid it out there." And later, "I for one think the man [Kennedy] deserves a medal. I could not be more impressed." Another proclaimed, "As great as their careers were, nothing has approached the courage and tenacity these two have shown in very publicly putting this creep back on ice for another two! Hats off, boys!"

\subsection{Perceived Failings of Sports Organizations in Preventing Sexual Abuse}

A sixth, and final, theme that emerged from the comments was a belief that the sex crimes of Graham James have exposed significant flaws within the institutions and organizations that govern youth sport in Canada. While only 19 comments were posted on this theme, it provides an important shift to focusing on how similar crimes might be prevented rather than simply addressing how they should be responded to after they occur. One commenter asks a series of questions: "Shouldn't more be done to prevent such acts? How did James do this in the first place and get away with it for so long? What were the other coaches doing? Why wasn't this prevented? What is being done now in Canadian sport to make sure it doesn't happen again?" Another commented, "Let's apply reason. Hockey Canada should accept some responsibility for this. This should have been prevented and never happened." Another, "There is such a lack of concern for things like this in sport that James will be back coaching in no time. Something has to change." One parent of youth athletes drew the conclusion, "I am pulling my children out of any sports that do not let me examine and ask questions about the leaders."

\section{Conclusion}

The general sentiment of commenters is of anger, disappointment, confusion, and shame. There is an overarching sentiment that the crimes of Graham James are appalling and have been mishandled by the Canadian Criminal Justice System. A further theme that could be added would be one of national shame to be a Canadian in the aftermath of Graham James's sex crimes against young hockey players and the legal response that they have generated. One commenter wrote, "Internationally, Canada has been shamed." Another wrote, "This is Canada's game, and James made a mockery of it. Hockey will never be the same. The absurd leniency of the courts has only added salt to these wounds. I am ashamed to be a Canadian after all of this." One commentator suggested that in the wake of this, "Canada is basically a haven for pedophiles." Another commenter stated, "I do not recognize this Canada."

There is a general sense that the overall legal handling of this case was not in keeping with the values of Canadians. This outcry, however, does not appear to have gone unnoticed by the Members of Parliament that form Canada's government (Leblanc, 2013). The federal government, under the leadership of Stephen Harper, has recently proposed a toughening of laws in the Canadian Criminal Code for adults who commit offences against children and youth in Canada. These changes will likely mean longer minimum sentences for offenders, like Graham James, who use sport as a vehicle to sexually prey on young athletes. Furthermore, on appeal by the prosecution in 2013 James's sentence has been increased to five years in prison.

While tougher penalties for child sexual offenders appear in keeping with the values and perspectives of Canadians based on the results of this study, there is still much work to be done in remedying the problem of sexual violence in amateur Canadian sport. The results of this study should also encourage providing increased support for victims of sexual violence in sport, as well as strengthening policies and strategies to help prevent sexual violence within amateur sports organizations.

\section{References}

Abbey, A., Zawacki, T., Buck, P., Clinton, M., \& McAuslan, P. (2004). Sexual assault and alcohol consumption: What do we know about their relationship and what types of research are still needed? Aggression and Violent Behaviour, 9(3), 271-303. http://dx.doi.org/10.1016/S1359-1789(03)00011-9

Anderson, L., \& Whiston, S. (2005). Sexual assault education programs: A meta- analytic examination of their $\begin{array}{lllll}\text { effectiveness. Psychology of Women } & \text { Quarterly, 29(4), }\end{array}$ http://dx.doi.org/10.1111/j.1471-6402.2005.00237.x

Anderson, V. Simpson, Taylor, D., \& Hermann, D. (2004). Gender, age, and sex- supportive rules. Sex Roles, 50, 
77-90. http://dx.doi.org/10.1023/B:SERS.0000011074.76248.3a

Arata, C. (1999). Coping with rape: The roles of priori sexual abuse and attributions of blame. Journal of Interpersonal Violence, 14(1), 62-78. http://dx.doi.org/10.1177/088626099014001004

Bachman, R. (1993). Predicting the reporting of rape victimizations: Have rape reforms made a difference? Criminal Justice and Behaviour, 25(1), 8-29. http://dx.doi.org/10.1177/0093854898025001002

Bachman, R., \& Taylor, B. (1994). The measurement of rape and family violence by the redesigned National $\begin{array}{llll}\text { Crime Victimization } & \text { Survey. Justice } & \text { Quarterly, } & \text { 11(3), }\end{array}$ http://dx.doi.org/10.1080/07418829400092371

Backhouse, C. (2008). Carnal crimes: Sexual assault law in Canada, 1900-1975. Toronto: Irwin Law.

Bagley, C., Bolithos, F., \& Bertrand, L. (1997). Sexual assault in school, mental health and suicidal behavior in adolescent women in Canada. Adolescence, 32, 361-366.

Benedict, J. (1997). Public heroes, private felons: Athletes and crimes against women. Boston, MA: Northeastern University Press.

Benedict, J., \& Klein, A. (1997). Arrest and conviction rates for athletes accused of sexual assault. Sociology of Sport Journal, 14, 86-94.

Benedict, J., \& Yaeger, D. (1998). Pros and cons: The criminals who play in the NFL. New York: Werner Books.

Beres, M., Crow, B., \& Gotell, L. (2009). The perils of institutionalization in neoliberal times: Results of a national survey of Canadian sexual assault and rape crisis centres. Canadian Journal of Sociology, 34(1), 135-163.

Berkowitz, A. (2002). Fostering men's responsibility for preventing sexual assault. In P. Schewe (Ed.), Preventing Violence in Relationships (pp. 163-196). Washington, DC: American Psychological Association. http://dx.doi.org/10.1037/10455-007

Bohner,G., Eyssel, F., Pina, A., Siebler, F., \& Tendayi, G. (2009). Rape myth acceptance: Cognitive, affective and behavioral effects of beliefs that blame the victim and exonerate the perpetrator. In M. Horvath, \& J. Brown (Eds.), Rape: Challenging Contemporary Thinking (pp. 17-45). Portland, OR: Willan Publishing.

Boocock, S. (2002). The child protection in sport unit. Journal of Sexual Aggression, 8(2), 99-106. http://dx.doi.org/10.1080/13552600208413342

Brackenridge, C. (1994). Fair play or fair game? Child sexual abuse in sport organisations. International Review for the Sociology of Sport, 29, 287-298. http://dx.doi.org/10.1177/101269029402900304

Brackenridge, C. (1997). 'He owned me basically': Women's experiences of sexual abuse in sport. International Review for the Sociology of Sport, 32, 115-130. http://dx.doi.org/10.1177/101269097032002001

Brackenridge, C. (1998). Healthy sport for healthy girls? The role of parents in preventing sexual abuse in sport. Sport, Education, and Society, 3(1), 59-78. http://dx.doi.org/10.1080/1357332980030104

Brackenridge, C. (1999). Managing myself: Investigator survival in sensitive research. International Review for the Sociology of Sport, 34, 399. http://dx.doi.org/10.1177/101269099034004007

Brackenridge, C. (2001). Spoilsports: Understanding and preventing sexual exploitation in sport. London: Routledge. http://dx.doi.org/10.4324/9780203478936

Brackenridge, C. (2003). Dangerous sports?: Risk, responsibility and sex offending in sport. Journal of Sexual Aggression, 9(1), 3-12. http://dx.doi.org/10.1080/1355260031000137922

Brackenridge, C. (2004). Women and children first? Child abuse and child protection in sport. Sport in Society, 7(3), 322-337. http://dx.doi.org/10.1080/1743043042000291668

Brackenridge, C., \& Fasting, K. (2002). Sexual harassment and abuse in sport: The research context. Journal of Sexual Aggression, 8(2), 3-15. http://dx.doi.org/10.1080/13552600208413336

Busby, K. (2007). Discriminatory uses of personal records in sexual violence cases. Canadian Journal of Women and the Law, 9, 148-177.

Campbell, R. (1998). The community response to rape: Victims' experiences with the legal, medical, and mental health system. American Journal of Community Psychology, 26(3), 355-379. http://dx.doi.org/10.1023/A:1022115322289 
Campbell, R. (2008a). Rape survivors' experiences with the legal and medical systems: Do rape victim advocates make a difference? Violence Against Women, 12(1), 30-45. http://dx.doi.org/10.1177/1077801205277539

Campbell, R. (2008b). The psychological impact of rape victims' experiences with the legal, medical, and $\begin{array}{lllll}\text { mental health } & \text { systems. } & \text { American } & \text { Psychologist, } & 63(8),\end{array}$ http://dx.doi.org/10.1037/0003-066X.63.8.702

Campbell, R., \& Ahrens, C. (1998). Innovative community services for rape victims: An application of multiple case study methodology. American Journal of Community Psychology, 26(4), 537-71. http://dx.doi.org/10.1023/A:1022140921921

Campbell, R., \& Bybee, D. (1997). Emergency medical services for rape victims: Detecting cracks in service delivery. Women's Health, 3(2), 75-101.

Campbell, R., \& Raja, S. (1999). Secondary victimization of rape victims: Insights from mental health professionals who treat survivors of violence. Violence and Victims, 14(3), 261-275.

Campbell, R., Dworkin, E., \& Cabral, G. (2009). An ecological model of the impact of sexual assault on women's health. Trauma, Violence, and Abuse, 10(3), 225- 246. http://dx.doi.org/10.1177/1524838009334456

Campbell, R., Patterson, D., \& Lichty, L. (2005). The effectiveness of Sexual Assault Nurse Examiner (SANE) programs: A review of psychological, medical, legal, and community outcomes. Trauma, Violence, and Abuse, 6(4), 313-329. http://dx.doi.org/10.1177/1524838005280328

Campbell, R., Wasco, S., Ahrens, C., Sefl, T., \& Barnes, H. (2001). Preventing the 'second rape': Rape survivors' experiences with community service providers. Journal of Interpersonal Violence, 16(12), 1239-1259. http://dx.doi.org/10.1177/088626001016012002

Caron, S., Halteman, W., \& Stacy, C. (1997). Athletes and rape: Is there a connection? Perceptual and Motor Skills, 85, 1379-1393. http://dx.doi.org/10.2466/pms.1997.85.3f.1379

Casey, E. \& Lindhorst, T. (2009). Toward a multi-level, ecological approach to the primary prevention of sexual assault: Prevention in peer and community contexts. Trauma, Violence, and Abuse, 10(2), 91-114. ttp://dx.doi.org/10.1177/1524838009334129

CBC News. (2012). Sex offender Graham James gets 2 years in prison. Retrieved from http://www.cbc.ca/news/canada/manitoba/story/2012/03/19/graham-james-sentence.html

Cense, M., \& Brackenridge, C. (2001). Temporal and developmental risk factors for sexual harassment and abuse in sport. European Physical Education Review, 7, 61-79. http://dx.doi.org/10.1177/1356336X010071006

Charmaz, K. (2006). Constructing Grounded Theory: A practical guide through qualitative analysis. Sage: Thousand Oaks, CA.

Chase, G. (1984). An analysis of the new sexual assault laws. Canadian Woman Studies, 4(4), 53-54.

Clark, L., \& Lewis, D. (1977) Rape: The price of coercive sexuality. Toronto: Women's Press.

Clark, S., \& Hepworth, D. (1994). Effects of reform legislation on the processing of sexual assault cases. In J. Roberts, \& R. Mohr (Eds.), Confronting Sexual Assault: A Decade of Legal and Social Change (pp. 113-135). Toronto: University of Toronto Press.

Cohen, L., \& Backhouse, C. (1980). Desexualizing rape: Dissenting view on the proposed rape amendments. Canadian Women Studies, 2(4), 99-103.

Crosset, T., Benedict, J., \& McDonald, M. (1995). Male-student athletes reported for sexual assault: A survey of campus police departments and judicial affairs offices. Journal of Sport and Social Issues, 19, 126-140. http://dx.doi.org/10.1177/019372395019002002

DeKeseredy, W., \& Kelly, K. (1995). Sexual abuse in Canadian university and college dating relationships: The contribution of male peer support. Journal of Family Violence, 10(1), 41-53. http://dx.doi.org/10.1007/BF02110536

Denike, M. (2004). Myths of women and the rights of man: The politics of credibility in Canadian rape law. In J. Hodgson, \& D. Kelley. Monsey (Eds.), Sexual Violence: Policies, Practices, and Challenges in the United States and Canada (pp. 101-118). NY: Criminal Justice Press. 
Dobash, R. P., Dobash, R. E., Wilson, M., \& Daly, M. (1992). The myth of sexual symmetry in marital violence. Social Problems, 39(1), 71-91. http://dx.doi.org/10.1525/sp.1992.39.1.03x00641

Donnelly, P. (1999). Who's fair game: Sport, sexual harassment, and abuse. In P. White, \& K. Young (Eds.), Sport and gender in Canada (pp. 107-128). Toronto: Oxford University Press.

DuMont, J. (2003). Charging and sentencing in sexual assault cases: An exploratory examination. Canadian Journal of Women and the Law, 15, 305-341.

DuMont, J., \& Myhr, T. (2000). So few convictions: The role of client-related characteristics in the legal processing of sexual assaults. Violence Against Women, 6(10), 1109-1136. http://dx.doi.org/10.1177/10778010022183541

DuMont, J., Miller, K., Myhr, T. (2003). The role of 'real rape' and 'real victim' stereotypes in the police reporting practices of sexually assaulted women. Violence Against Women, 9(4), 466-486. http://dx.doi.org/10.1177/1077801202250960

Fasting, K., \& Brackenridge, C. (2009). Coaches, sexual harassment and education. Education and Society, 14(1), 21-35.

Fasting, K., Brackenridge, C., \& Sundgot-Borgen, J. (2004). Prevelance of sexual harassment among Norwegian female elite athletes in relation to sport type. International Review for the Sociology of Sport, 39, 373-386. http://dx.doi.org/10.1177/1012690204049804

Fasting, K., Brackenridge, C., \& Walseth, K. (2002). Consequences of sexual harassment in sport for female athletes. Journal of Sexual Aggression, 8(2), 37-48. http://dx.doi.org/10.1080/13552600208413338

Fasting, K., Brackenridge, C., \& Walseth, K. (2007). Women athletes' personal responses to sexual harassment in sport. Journal of Applied Sport Psychology, 19(4), 419-433. http://dx.doi.org/10.1080/10413200701599165

Fasting, K., Brackenridge, C., Miller, K., \& Sabo, D. (2008). Participation in college sports and protection from sexual victimization. International Journal of Sport and Exercise Psychology, 6(4), 427-441. http://dx.doi.org/10.1080/1612197X.2008.9671883

Finch, E., \& Munro, V. (2005). Juror stereotypes and blame attribution in rape cases involving intoxicants. British Journal of Criminology, 45, 25-38. http://dx.doi.org/10.1093/bjc/azh055

Finch, E., \& Munro, V. (2007). The demon drink and the demonized woman: Socio- sexual stereotypes and responsibility attribution in rape trials involving intoxicants. Social and Legal Studies, 16(4), 591-614. http://dx.doi.org/10.1177/0964663907082737

Firsten, T. (1990). An exploration of the role of physical and sexual abuse for psychiatrically institutionalized women. Toronto: Ontario Women's Directorate.

Fisher, B. (2009). The effects of survey question wording on rape estimates: Estimates from a

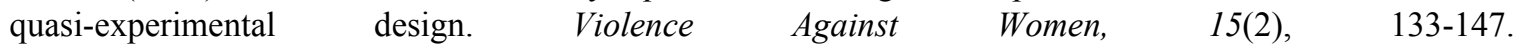
http://dx.doi.org/10.1177/1077801208329391

Fisher, B., Daigle, L., \& Cullen, F. (2008). Rape against women: What can research offer to guide the development of prevention programs and risk reduction interventions? Journal of Contemporary Criminal Justice, 24(2), 163-177. http://dx.doi.org/10.1177/1043986208315482

Fisher, B., Daigle, L., Cullen, F., \& Turner, M. (2003). Reporting sexual victimization to the police and others. Criminal Justice and Behavior, 30(1), 6-38. http://dx.doi.org/10.1177/0093854802239161

Frith, H. (2009). Sexual scripts, sexual refusals and rape. In M. Horvath, \& J. Brown (Eds.), Understanding Rape: Challenging Contemporary Thinking. Portland, OR: Willan.

Glaser, B., \& Strauss, A. (1967). The discovery of Grounded Theory: Strategies for qualitative research. New Jersey: Transaction.

Gotell, L. (2002). The ideal victim, the hysterical complainant and the disclosure of confidential records: A case study of the implications of the Charter for sexual assault law. Osgoode Hall Law Journal, 40 (3), 251-294.

Gotell, L. (2007). The discursive disappearance of sexualized violence: Feminist law reform, judicial resistance and neoliberal sexual citizenship. In D. Chunn, S. Boyd, \& H. Lessard (Eds.), Reaction and Resistance: Feminism, Law and Social Change (pp. 127-163). Vancouver: University of British Columbia Press.

Griffiths, J. (1999). Review of the investigation of sexual assaults by the Toronto Police Service. Toronto: 
Toronto Auditor General.

Groeneveld, J., \& Shane, M. (1989). Drug abuse among victims of physical and sexual abuse: A preliminary report. Toronto: Addiction Research Foundation.

Harris, J., \& Grace, S. (1999). A question of evidence? Investigating and prosecuting rape in the 1990s. London: Home Office.

Hartill, M. (2005). Sport and the sexually abused male child. Sport, Education, and Society, 10(3), 287-304. http://dx.doi.org/10.1080/13573320500254869

Hartill, M. (2008). The sexual abuse of boys in organized male sports. Men and Masculinities, 12, 225-249. http://dx.doi.org/10.1177/1097184X07313361

Hartill, M., \& Prescott, P. (2007). Serious business or "any other business"?: Safeguarding and child protection in British Rugby League. Child Abuse Review, 16(4), 237-251. http://dx.doi.org/10.1002/car.990

Horvath, M., \& Brown, J. (2007). Alcohol as drug of choice: Is drug-assisted rape a misnomer? Psychology, Crime and Law, 13(5), 417-429. http://dx.doi.org/10.1080/10683160601061117

Jackson, T. (1991). A university athletic department's rape and assault experiences. Journal of College Student Development, 32, 77-78.

Johnson, J., \& Holman, M. (Eds.). (2004). Making the team: the inside world of sport initiations and hazing. Toronto: Canadian Scholar's Press.

Jones, H., \& Cook, K. (2008). Rape crisis: Responding to sexual violence. Lyme Regis, UK: Russell House Publishing.

Jordan, J. (2004). Beyond belief?: Police, rape and women's credibility. Criminal Justice, 4(29), 29-59.

Jordan, J. (2008). Serial survivors: Women's narratives of surviving rape. Sydney: Federation Press.

Kane, M., \& Disch, L. (1993). Sexual violence and the reproduction of male power in the locker room: The "Lisa Olson incident." Sociology of Sport Journal, 10(4), 331-352.

Kelly, L., Lovett, J., \& Reagan. L. (2005). A gap or a chasm? Attrition in reported rape cases. London: Home Office.

Kidd, B., \& Donnelly, P. (Eds.). (2007). The Benefits of Sport in International Development: Five Literature Reviews. Geneva: Switzerland: International Working Group for Sport, Development and Peace.

Kirby, S. (1995). Not in my backyard: Sexual harassment and abuse in sport. Canadian Woman Studies, 15(4), 58-62.

Kirby, S., \& Wintrup, G. (2002). Running the gauntlet: An examination of initiation/hazing and sexual abuse in sport. Journal of Sexual Aggression, 8(2), 49-68. http://dx.doi.org/10.1080/13552600208413339

Kirby, S., Demers, G., \& Parent, S. (2008). Vulnerability/prevention: Considering the needs of disabled and gay athletes in the context of sexual harassment and abuse. International Journal of Sport and Exercise Psychology, 6(4), 407-426. http://dx.doi.org/10.1080/1612197X.2008.9671882

Kirby, S., Greaves, L., \& Hankivsky, O. (2000). The dome of silence: Sexual harassment and abuse in sport. London: Zed Books.

Kirkpatrick, C., \& Kanin, E. (1957). Male sex aggression on a university campus. American Sociological Review, 22(1), 52-58. http://dx.doi.org/10.2307/2088765

Koss, M. (1992). The underdetection of rape: Methodological choices influence incidence estimates. Journal of Social Issues, 48(1), 61-75. http://dx.doi.org/10.1111/j.1540-4560.1992.tb01157.x

Koss, M. (1993). Detecting the scope of rape: A review of prevalence research methods. Journal of Interpersonal Violence, 8(2), 198-222. http://dx.doi.org/10.1177/088626093008002004

Koss, M., Bachar, K., \& Quince-Hopkins, C. (2003). Restorative justice for sexual violence: Repairing victims, building community and holding offenders accountable. Annals of the New York Academic of Science, 989, 384-396. http://dx.doi.org/10.1111/j.1749-6632.2003.tb07320.x

Leahy, T. (2008). Understanding and preventing sexual harassment and abuse in sport: Implications for the sport psychology profession. International Journal of Sport and Exercise Psychology, 6(4), 351-353. http://dx.doi.org/10.1080/1612197X.2008.9671878 
Leahy, T., Pretty, G., \& Tenenbaum, G. (2002). Prevalence of sexual abuse in organised competitive sport in Australia. Journal of Sexual Aggression, 8(2), 16-36. http://dx.doi.org/10.1080/13552600208413337

Leblanc, D. (2013). Tories to announce tougher sentences for child predators. Retrieved from http://www.theglobeandmail.com/news/politics/tories-to-announce-tougher-sentences-for-child-predators/ar ticle $8158009 /$.

Lefkowitz, B. (1997). Our guys: The Glen Ridge rape and secret life of the perfect suburb. Berkeley: University of California Press.

Lievore, D. (2005). No longer silent: A study of women's help-seeking decisions and service responses to sexual assault. Canberra: Australian Institute for Criminology and Office for Women.

Lonsway, K. (1996). Preventing acquaintance rape through education: What do we know? Psychology of Women Quarterly, 20(2), 229-265. http://dx.doi.org/10.1111/j.1471-6402.1996.tb00469.x

Lyons, K. (2002). Confronting sexual exploitation in sport. Journal of Sexual Aggression, 8(2), 111-117. http://dx.doi.org/10.1080/13552600208413344

Maier, S. (2008a). Are rape crisis centers feminist organizations? Feminist Criminology, 3(2), 82-100. http://dx.doi.org/10.1177/1557085107310623

Maier, S. (2008b). 'I have heard horrible stories...' Rape victim advocates' perceptions of the revictimization of rape victims by the police and medical system. Violence Against Women, 14(7), 786-808. http://dx.doi.org/10.1177/1077801208320245

Markovitz, J. (2006). Anatomy of a spectacle: Race, gender, and memory in the Kobe Bryant rape case. Sociology of Sport Journal, 23, 396-418.

Marks, S., Mountjoy, M., \& Marcus, M. (2011). Sexual harassment and abuse in sport: The role of the team doctor. British Journal of Sports Medicine, 47, 905-908.

McFarlane, J., Malecha, A., Gist, J., Watson, K., Batten, E., Hall, I., \& Smith, S. (2005). Intimate partner sexual assault against women and associated victim substance use, suicidality, and risk factors for femicide. Issues in Mental Health Nursing, 27(1), 64-69.

McGregor, M., Janssen, P., Ericksen, J., Van Vliet, A., Ronald, L., \& Schulzer, M. (2004). Rising incidence of hospital reported drug-facilitated sexual assault in a large urban community in Canada: Retrospective population-based study. Canadian Journal of Public Health, 95, 441-445.

McIntyre, S., Boyle, C., Lakeman, L., \& Sheehy, E. (2000). Tracking and resisting backlash against equality gains in sexual offence law. Canadian Woman Studies, 20(3), 72-84.

Murnen, S., Wright, C., \& Kaluzny, G. (2002). If 'boys will be boys,' then girls will be victims? A meta-analytic review of the research that relates masculine ideology to sexual aggression. Sex Roles, 46(11), 359-75. http://dx.doi.org/10.1023/A:1020488928736

Nielsen, J. (2001). The forbidden zone: Intimacy, sexual relations, and misconduct in the relationship between coaches and athletes. International Review of the Sociology of Sport, 36, 165-182. http://dx.doi.org/10.1177/101269001036002003

Pappas, N., McKenry, P., \& Catlett, B. (2004). Athletes aggression on the rink and off the ice: Athlete violence and aggression in hockey and interpersonal relationships. Men and Masculinities, 6, 291-312. http://dx.doi.org/10.1177/1097184X03257433

Parent, S. (2011). Disclosure of sexual abuse in sport organizations: A case study. Journal of Child and Sexual Abuse, 20(3), 322-337. http://dx.doi.org/10.1080/10538712.2011.573459

Parrot, A., \& Cummings, N. (1994). A rape awareness and prevention model for male athletes. Journal of American College Health, 42(4), 179-184. http://dx.doi.org/10.1080/07448481.1994.9939668

Percy, A., \& Mayhew, P. (1997). Estimating sexual victimization in a national crime survey: A new approach. Studies on Crime and Crime Prevention, 6(2), 125- 150.

Peterson, Z., \& Muelenhard, C. (2004). Was it rape? The function of women's rape myth acceptance and definitions of sex in labeling their own experiences. Sex Roles, 51(3), 129-144. http://dx.doi.org/10.1023/B:SERS.0000037758.95376.00

Quinlan, A. (2012). Imagining a feminist Actor-Network Theory. International Journal of Actor-Network Theory and Technological Innovations, 4(2), 1-9. http://dx.doi.org/10.4018/jantti.2012040101 
Quinlan, A., Fogel, C., \& Quinlan, E. (2010). Unmasking scientific controversies: Forensic DNA analysis in Canadian legal cases of sexual assault. Canadian Woman Studies, 28, 98-108.

R. v. James [2012]. MBPC 31.

Randall, M. (2008). Sexual assault in spousal relationships, 'continuous consent', and the law: Honest but mistaken judicial beliefs. Manitoba Law Journal, 32(2), 144-181.

Randall, M., \& Haskell, L. (1995). Sexual violence in women's lives: Findings from the Women's Safety Project, a community---based survey. Violence Against Women, 1(1), 6-31. http://dx.doi.org/10.1177/1077801295001001002

Roberts, J. \& Gebotys, R. (1992). Reforming rape laws: Effects of legislative change in Canada. Law and Human Behavior, 16(5), 555-573. http://dx.doi.org/10.1007/BF01044623

Roberts, J., Grossman, M., \& Gebotys, R. (1996). Rape reform in Canada: Public knowledge and opinion. Journal of Family Violence, 11(2), 133-148. http://dx.doi.org/10.1007/BF02336666

Roberts, J., Johnson, H., \& Grossman, M. (2003). Trends in crimes of sexual aggression in Canada: An analysis of police-reported and victimization statistics. International Journal of Comparative Criminology, 2(2), 187-200.

Robinson, L. (1998). Crossing the line: Violence and sexual assault in Canada's national sport. Toronto: McClelland \& Stewart.

Rumney, P. (2006). False allegations of rape. Cambridge Law Journal, 65(1), 128-158. http://dx.doi.org/10.1017/S0008197306007069

Russell, D. (1975). The politics of rape: The victim's perspective. New York: Stein and Day.

Sanday, P. (1981). The socio-cultural context of rape: A cross-cultural study. Journal of Social Issues, 37, 5-27. http://dx.doi.org/10.1111/j.1540-4560.1981.tb01068.x

Sanday, P. (1990). Fraternity gang rape: Sex, brotherhood and privilege on campus. New York: New York Press.

Sanday, P. (1996). A women scorned: Acquaintance rape on trial. New York: Doubleday.

Schwartz, M., \& DeKeseredy, W. (1997). Sexual assault on college campus: The role of male peer support. Thousand Oaks, CA: Sage.

Sheehy, E. (1996). Legalising justice for all women: Canadian women's struggle for democratic rape law reforms. The Australian Feminist Law Journal, 6, 87-113.

Silva, J. M. (1983). The perceived legitimacy of rule violating behaviour in sport. Journal of Sport Psychology, $5(4), 438-448$.

Smith, D., \& Stewart, S. (2003). Sexual aggression and sports participation. Journal of Sport Behavior, 26(4), 384-395.

Temkin, J. (2002). Rape and legal process. New York: Oxford. http://dx.doi.org/10.1093/acprof:oso/9780198763550.001.0001

Temkin, J., \& Krahe, B. (2008). Sexual assault and the justice gap: A question of attitude. Oxford: Hart Publishing.

Temple, J., Weston, R., Rodriguez, B., \& Marshall, L. (2007). Differing effects of partner and nonpartner sexual assault on women's mental health. Violence Against Women, 13(3), 285-297. http://dx.doi.org/10.1177/1077801206297437

The Star. (2012). A look at Graham James, his coaching career and history with the legal system. Retrieved from http://www.thestar.com/sports/hockey/2012/02/22/a_look_at_graham_james_his_coaching_ca reer_and_history_with_the_legal_system.html.

Ullman, S. (2003). A critical review of field studies on the link of alcohol and adult sexual assault in women. Aggression and Violent Behaviour, 8, 471-486. http://dx.doi.org/10.1016/S1359-1789(03)00032-6

Ullman, S., \& Filipas, H. (2001). Predictors of PTSD symptom severity and social reactions in sexual assault victims. Journal of Traumatic Stress, 14(2), 369-389. http://dx.doi.org/10.1023/A:1011125220522

Vaz, E. W. (1982). The professionalization of young hockey players. Lincoln, NE: University of Nebraska Press. 
Volkwein-caplan, K., \& Sankaran, G. (2001). Sexual harassment in sport: Issues, impacts, and challenges. Aechen, Germany: Meyer \& Meyer.

Volkwein-caplan, K., Schnell, F., Mitchell, M., \& Sutera, J. (2002). Sexual harassment of women in athletics vs. academia. Journal of Sexual Aggression, 8(2), 69-82. http://dx.doi.org/10.1080/13552600208413340

Volkwein-caplan, K., Schnell, F., Sherwood, D., \& Livezey, A. (1997). Sexual harassment in sport: Perceptions and experiences of American female student-athletes. International Review for the Sociology of Sport, 32, 283-295. http://dx.doi.org/10.1177/1012690297032003005

Ward, C. (1995). Attitudes toward rape: Feminist and social psychological perspectives. London: Sage.

Webb, E. J., Campbell, D., Schwartz, R., \& Sechrest, L. (2000). Unobtrusive measures. Thousand Oaks, CA: Sage Publications.

Weiss, K. (2009). 'Boys will be boys' and other gender accounts: An exploration of victims' excuses and justifications for unwanted sexual contact and coercion. Violence Against Women, 15(7), 810-834. http://dx.doi.org/10.1177/1077801209333611

Welch, M. (1997). Violence against women by professional football players: A gender analysis of hypermasculinity, positional status, narcissism, and entitlement. Journal of Sport and Social Issues, 21(4), 392-411. http://dx.doi.org/10.1177/019372397021004006

Williams, J., \& Holmes, K. (1981). The second assault: Rape and public attitudes. Westport, CT: Greenwood Press.

Wintrup, G. (2003). Sportization and hazing: Global sport culture and the differentiation of initiation from harassment in Canada's sport policy. (Unpublished Master's Thesis). University of Manitoba.

Young, K. (1991). Violence in the workplace of professional sport from victimological and cultural studies perspectives. International Review for the Sociology of Sport, 26, 3-13. http://dx.doi.org/10.1177/101269029102600102

Yves, V., Opdenacker, J., Vertommen, T., Boen, F., Van Niekerk, L., De Martelaer, K., \& De Cuyper, B. (2008). Unwanted sexual experiences in sport: Perceptions and reported prevalence among Flemish female student-athletes. International Journal of Sport and Exercise Psychology, 6(4), 354-365. http://dx.doi.org/10.1080/1612197X.2008.9671879

\section{Copyrights}

Copyright for this article is retained by the author(s), with first publication rights granted to the journal.

This is an open-access article distributed under the terms and conditions of the Creative Commons Attribution license (http://creativecommons.org/licenses/by/3.0/). 